\title{
The Impact of Textual Input Enhancement and Explicit Rule Presentation on Iranian Elementary EFL Learners' Intake of Simple Past Tense
}

\author{
Naemeh Nahavandi ${ }^{1} \&$ Jayakaran Mukundan ${ }^{1}$ \\ ${ }^{1}$ Department of Language and Humanities Education, Faculty of Educational Studies, Universiti Putra Malaysia, \\ Malaysia
}

Correspondence: Jayakaran Mukundan, Department of Language and Humanities Education, Faculty of Educational Studies, Universiti Putra Malaysia, 43400 UPM Serdang, Selangor, Malaysia. Tel: 12-209-9717. Fax: 603-8943-5386. E-mail: jayakaranmukundan@yahoo.com

Received: November 7, 2012 Accepted: November 22, 2012 Online Published: December 12, 2012

doi:10.5539/elt.v6n1p92 URL: http://dx.doi.org/10.5539/elt.v6n1p92

\begin{abstract}
The present study investigated the impact of textual input enhancement and explicit rule presentation on 93 Iranian EFL learners' intake of simple past tense. Three intact general English classes in Tabriz Azad University were randomly assigned to: 1) a control group; 2) a TIE group; and 3) a TIE plus explicit rule presentation group. All participants were given 3 reading texts and comprehension questions to complete. For participants in groups 2 and 3 the input was textually enhanced through bolding. Participants in group 3 in addition had explicit rule presentation of simple past tense. Intake of simple past tense was measured through performance on a Multiple-Choice Recognition Tests. The results showed that there was a significant difference among pretest, first posttest and delayed posttest. Posttest 1 was significantly higher than posttest 2 . Furthermore, TE + rule presentation group significantly outperformed the control group in both posttest1 and posttest 2 . The study concluded with some pedagogical implications.
\end{abstract}

Keywords: textual input enhancement, explicit rule presentation, Iranian EFL learners, past tense

\section{Introduction}

In the field of second language acquisition (SLA) the nature of linguistic input in L2 acquisition has always been a controversial issue. Over the past decades, the controversy over either direct or indirect instruction of language forms has always been challenged. The role of grammar instruction has undergone lots of changes both in theory and in practice. At first, learning a language was considered as learning grammatical systems via rote learning, a method of rote memorization of sets of prescribed rules and repetitive drills for each targeted rule. This method of learning a language can be traced to the $16^{\text {th }}$ century in which people learned Latin through reading classical Latin literature. Those days one concern was about how to translate Latin texts into other languages and vice versa. However, the traditional grammar-driven teaching approaches which involved various pedagogical manifestations like audio-lingual methods and total physical response in the mid- twentieth century came under attack with the advent of communicative approaches in the 1980s. Critics of grammar-driven approaches argued that language learners taught with these methods are less competent when they are faced with real time communication in the target language. As a result of these problems classroom activities were designed in a way to achieve communicative competence (Canale \& Swain, 1980), and grammar instruction was not thought effective and was sometimes considered harmful. The idea of placing an importance on the role of meaning was inspired by Krashen's input hypothesis which claimed that language learning occurs by the comprehensible input. As a result of this theory, lots of meaning-focused pedagogical choices like communicative language teaching, immersion programs, the natural approach and content based instruction emerged. However, case studies showed less than satisfactory learning outcomes by individuals who were exposed to natural learning environments. For Simard \& Wong (2004) "a pure focus on meaning in 12 learning does not lead to high levels of linguistic accuracy" (p. 96). Trevise (1993, cited in Gascoigne, 2006) claims that the removal of grammatical and pedagogical metalanguage from the communicative classroom can result lots of linguistic deficiencies. Due to the inadequacy of the approaches favoring either form or meaning with the exclusion of one or the other, the 1990s witnessed approaches pursuing the combination of the two learning targets of form and meaning, 
including Long's $(1991,1998)$ focus on form, Schmidt's $(1993,2001)$ noticing hypothesis, Smith's (1993) input enhancement, and Van pattern's (1994, 2004) processing instruction.

During the last 2 decades or so, visual input enhancement studies have been conducted to achieve the goal of teaching grammatical elements implicitly, mostly through reading activities (Alanen 1995; Cho 2010; Combs 2008; Doughty 1991; Izumi 2002; Gascoigne, 2006; Kelly 2008; Lee 2007; Lee \& Haung 2008; Leow 1998, 2001; Leow \& Morgan-Short, 2004; Mueller 2010; Overstreet 1998; Rezvani 2011; Sarkhosh 2012; Simard 2009; Song 2007; White 1998; Wong 2003, 2005) and the method has been described as the least explicit and the least intrusive method of focus on form (Doughty \& Varela, 1998).

In summary, the existing literature on the effect of visual input enhancement have shown a small-sized positive effect, but different researchers have come to different conclusions on the efficacy of such implicit type of focus on form technique. As a result, due to the wide discrepancies in methodological features, reliable comparison across studies has been an extremely difficult task. Lots of other factors might constrain or qualify the effects of visual input enhancement on 12 grammar learning. These factors involve learner related variables like proficiency level, prior knowledge of the target language, the developmental stage and the degree of readiness of the learner. Therefore, due to the contradictory results, more research in this area especially EFL context seemed necessary.

\section{Literature Review}

\subsection{Focus on Form (FonF) VS. Focus on Forms (FonFs)}

Long (1991) claims that grammar instruction can be of two types: "focus on form" and "focus on forms". FonF refers to drawing learners' attention to form as they arise incidentally in classroom. However, FonFs refers to teaching of discreet points of grammar in separate lessons. Considering the theoretical underpinnings of these two options, there is an essential difference. FonF derives from an assumed degree of similarity between first and second language acquisition claiming that these two processes are both based on an exposure to comprehensible input which arises from natural interaction (Sheen, 2002). Nevertheless, it is also claimed that there are fundamental differences in these two processes. Researchers claim that mere exposure is insufficient in enabling learners to acquire much of the second language grammar, and this lack should be compensated through focusing learners' attention to grammatical features. On the other hand FonFs is based on the idea that classroom second or foreign language drives from cognitive processes, entailing the learning of a skill. Therefore, it should be characterised as skill learning approach (Sheen, 2002). Harmer (2007) claims that FonF occurs when students direct their conscious attention to some feature of the language, like verb tense or the organization of paragraphs. It should occur naturally while students try to complete communicative tasks in Task-based learning. For Harmer, FonF is often incidental and opportunistic, growing out of tasks which students are involved in, rather than being pre-determined by a book or syllabus (p. 53).

\subsection{Textual Input Enhancement}

Unlike traditional grammar instruction where the manipulation of learner output is done to affect changes in their developing system, the aim of TIE is to change the way input is perceived and processed by language learners. TE includes highlighting special features of input which might go unnoticed under normal circumstances through typographically manipulating them. Different techniques have been used to enhance input or increase the saliency of given features of an 12. These techniques rang from explicit discussion of target forms, metalinguistic descriptions, negative evidence through overt error correction, input floods, clarification requests, processing instruction, garden-path techniques to textual input enhancement by typographical changes through boldfacing, italicizing, underlining, or capitalizing. The idea for textual enhancement is that such manipulations increase the perceptual saliency of the target structures, and this, hence, increases their chance of being noticed. One technique that has been applied by a great number of researchers, is the provision of numerous instances of target linguistic forms in the input, called an input flood (Trahey \& White, 1993). Similarly, the assumption is that frequent exposure to target items enhances their saliency and therefore results in noticing the forms (Schmidt, 1993; Sharwood Smith, 1993).

Based on the focus on form literature the input which is typographically enhanced through a range of enhancement cues such as (bold facing, colour-coding, underlining, italicizing, capitalizing, and using different font types and sizes) attracts more attention from learners (Doughty \& Wiliams, 1998; Long 1991; Long \& Robinson 1998; Wong 2005). These types of added attention might lead to notice more of the targets and to process them for more subsequent acquisition (Robinson 1995, 1997, Schmidt 1993, 1995, 2001). As (Izumi 2002; Lee 2007; Lee \& Huang 2008) claim the use of varied typographical cues increase the physical salience of input. In addition, when the input is made physically salient, it is likely to gather more attention from the learner 
(Goldschneider \& Dekeyser 2005; C. D. Doughty 2003; Gass \& Mackey 2002) which will later lead to subsequent processing of the input easier.

Lee (2007) has reviewed 13 studies on input enhancement, claiming that the previous literature have produced inclusive results. Of the 13 reviewed studies, five have reported facilitative effects of such a pedagogical choice in teaching grammar. On the contrary, the other eight studies have failed to find statistically significant benefits of visual input enhancement. For Lee (2007), the mixed results might be in part attributable to varied study designs and a wide array of tasks to measure the extent of acquisition. Lee \& Huang (2008) did a meta-analysis of the previous literature. They not only focused on the particular design characteristics of empirical studies, but also on the effects of textual input enhancement on grammar learning. The meta-analysis showed that input enhancement group did not outperform the other unenhanced group. However, they found out that, learners who read enhancement-embedded texts showed slight improvement from before to after the treatment. Lee \& Huang (2008) reported that previous studies differed extensively in terms of their methodological features, like learner characteristics, research design, and treatment intensity.

\subsection{Research Questions}

To address some of the gaps in the existing literature reviewed above, the present study tries to examine:

1. Whether textual input enhancement affects Iranian EFL learners' intake of simple past tense or not.

2. Whether textual input enhancement+ explicit rule presentation affects Iranian EFL learners' intake of simple past tense or not.

3. Whether there is a significant difference between male and female learners in their intake of simple past tense or not.

\section{Methodology}

\subsection{Design of the Study}

The present study employed an experimental design with pretest, treatment, and posttest design. The participants completed the pretest and were randomly assigned to the treatment and control group (including two experimental groups and one control group). The treatment groups were (1) the TE group, (2) the TE group + rule presentation, and (3) control group. The participants in the treatment groups completed a treatment task according to their group designation. The post-test was administered one day after the last treatment session, and delayed post test was administered 2 weeks later.

\subsection{Participants}

The participants of the present study were 111 elementary learners in Azad university of Tabriz, Iran registering in General English course during February 2012. All 3 classes were mixed classes including male and female students with the age range of 19 to 40. It was expected that participants were at the level where they had learnt the English simple past tense, but had not yet developed full mastery of the form. All participants were assigned to one of three treatment groups based on the class they were enrolled in. In order to make sure that the participants were all at the same level of proficiency regarding their knowledge of English simple past tense, a pretest was administered. Out of 111 participants, 9 achieved more than 90 per cent on the test. These participants were present in all treatment and posttests sessions but their scores were not reported in the study. Participants in class $1(\mathrm{~N}=35)$ were assigned to a control group, participants in class 2 to TIE only group ( $\mathrm{N}=$ $34)$, and participants in class $3(\mathrm{~N}=33)$ were assigned to the TIE plus rule presentation (TIE + rule presentation) group. The result of the pretest indicated that there was no significant difference among groups at pretest. Therefore, all groups were similar at the beginning of the study. Also, it was made sure that the target form was not covered in class during the experimental period. This study was conducted with the consent of participation with an indication of the general purposes and procedures of the study. However, other 9 students who were not present in all treatment sessions and 2 posttests were eliminated from the population pool. Therefore the results of only 93 students are reported in the present study.

\subsection{Target Structure}

For Ferris (2004) linguistic categories are divided into treatable and non treatable one. The first category includes the structures that are easily rule-bound making it easier to formulate a rule in how to apply them, like English tenses or conditionals. However, the second category refers to the structures which do not easily let the formulation of clear-cut rules in how to use them, like English prepositions or article system. Furthermore, as Harley (1993) claims English simple past tense is an appropriate form in FonF instruction, as it is different in non-obvious ways from the learners' first language and as it is probably misinterpreted by learners. In addition, 
Bitchener, (2008) claims that TE might be more effective on treatable error categories since written corrective feedback proved to be more effective on treatable error categories in the studies of error correction. For Schwartz (1993) inflectional endings are among the most difficult features of non-native languages for adult learners' "highest amount of variability and lowest degree of success" (p. 160). For Larsen (2002) the aspects of inflectional morphology are notable areas for learners of all proficiency levels. Therefore, the expected difficulty of past tense for Iranian learners and insufficient studies on this form inspired the researcher to investigate whether TE can benefit learners in acquiring this form or not.

\subsection{Instruments}

\subsubsection{Demographical Information}

To obtain necessary demographical information about the subjects like, age, gender, educational level, and major of study first a demographical questionnaire was distributed among the subjects in the first session together with the pretest.

\subsubsection{Reading Texts}

Three reading comprehension passages consisting 270 words from Active skills for reading (1) were selected. The participants in the experimental groups read the text including simple past tenses highlighted via bolding. However, participants in the control group read the same texts without highlighting the past tenses.

\subsubsection{Multiple-choice Recognition Tests}

To check the students' intake of the simple past tense in both pre and posttests multiple-choice recognition tests were used. The reason for using this kind of tests was based on (Leow, 1997; Overstreet, 1998) studies which proved to be effective in exploring the impact of TE on intake. Two parallel versions of a multiple-choice recognition test namely as (A \& B), were developed one for pretest and one for two posttests, and each version had 35 questions. Each question was scored 1, therefore the total mark was 35 . In order to be sure that both tests were equal, a pilot study was conducted in which all past simple questions of pretest and posttest (90 questions) were put together into one test. Even numbers were assigned to pretest questions and odd numbers to posttest questions. The new test was administered to one elementary class of EFL learners at Jahad-e- daneshgahi institute. Twenty too easy, too difficult questions were eliminated. Then two parts of the test, pretest and posttests questions (70 questions) were scored separately and the correlation coefficient between them was analyzed to see whether the two versions were parallel and it turned out to be 0.75 .

\subsection{Data Collection}

\subsubsection{Procedure}

The experimental part of the study took place over 1 month. The first week, participation agreement for the experiment was obtained and the level test was carried out together with the first treatment. It is worth noting that the reading texts were obtained from Active reading (1). It involved the reading of the first text (about Jamie Oliver's School Dinners) and doing comprehension tasks (multiple choice questions). The Second week second treatment was administered, which incorporated the exact same method as the first treatment but with a different text (The High School That Beat MIT). The third week third treatment was given (My Year Abroad). Each treatment session lasted for about 90 minutes. The fourth week a post-test was administered, lasting 40 minutes. Finally, Two weeks later another posttest was administered lasting 40 minutes.

\subsection{Data Analysis}

In this study, the independent variable was the instructional method which had two levels: textual input enhancement and TE + explicit rule presentation. The dependent variable was the participants' intake of simple past tense. The design to carry out this study was experimental, with a pretest, three different treatments for experimental and control groups, as well as two post-tests. To answer the research questions regarding the difference between two different instructions, two way ANOVA (mixed ANOVA) was used.

\section{Results of the Study}

\subsection{Demographical Information of Participants}

The obtained data in the present study were analyzed by using the (SPSS), version 20. Table 1 and table 2 show the information related to the participants gender and age in all three groups. 
Table 1. Information about gender

\begin{tabular}{|c|c|c|c|c|c|}
\hline \multirow{2}{*}{$\begin{array}{l}\text { Group } \\
\text { Control }\end{array}$} & & \multicolumn{4}{|c|}{ FrequencyPercentValid PercentCumulative Percent } \\
\hline & Male & 17 & 54.8 & 54.8 & 54.8 \\
\hline & Female & & 45.2 & 45.2 & 100.0 \\
\hline & Total & 31 & 100.0 & 100.0 & \\
\hline \multirow[t]{3}{*}{$\mathrm{TE}$} & Male & 13 & 41.9 & 41.9 & 41.9 \\
\hline & Female & & 58.1 & 58.1 & 100.0 \\
\hline & Total & 31 & 100.0 & 100.0 & \\
\hline \multirow[t]{3}{*}{$\mathrm{TE}+$ rule } & ale & 14 & 45.2 & 45.2 & 45.2 \\
\hline & Female & & 54.8 & 54.8 & 100.0 \\
\hline & Total & 31 & 100.0 & 100.0 & \\
\hline
\end{tabular}

As can be seen in table1 all groups (control, TE, and TE + rule presentation) include 31 participants. From all 93 learners 47.3 were male and 52.7 were female. Control group included 54.8 male and 45.2 female students. TE group included 41.9 male and 58.1 female students. And finally, TE + rule presentation group included 45.2 male and 54.8 female students respectively.

Table 2. information about age

\begin{tabular}{llllll}
\hline Group & $\mathrm{N}$ & Mean & Std. Deviation & Minimum & Maximum \\
\hline Control & 31 & 23.35 & 4.021 & 20 & 36 \\
\hline TE & 31 & 23.68 & 5.694 & 19 & 40 \\
\hline TE + rule presentation & 31 & 21.87 & 3.452 & 19 & 34 \\
\hline Total & 93 & 22.97 & 4.512 & 19 & 40 \\
\hline
\end{tabular}

As can be seen in table 2, all groups included 31 students. As table 2 shows, the average mean of age in control, $\mathrm{TE}$, and TE+ rule presentation are $23.35,23.68$ and 21.87 respectively. In control group the minimum and maximum age are 20 and 36, while in TE it is 19 and 40, and in TE+ rule presentation it is 19 and 40 respectably.

\subsection{Test of Normality}

Table 3. One-Sample Kolmogorov-Smirnov Test

\begin{tabular}{llll}
\hline & $\mathrm{N}$ & Kolmogorov-Smirnov Z & Asymp. Sig. (2-tailed) \\
\hline pre & 93 & 1.000 & .270 \\
\hline post1 & 93 & 1.015 & .254 \\
\hline post2 & 93 & .826 & .503 \\
\hline
\end{tabular}

To test the normality of the distribution, a Kolmogorov-Smirnov test was run. The results indicated that distribution of the scores at all levels of pretest, posttest1, and posttest 2 was normal (Significant level > 0/05).

\subsection{Comparing Pretests in All Groups}

Based on the obtained results parametric statistics was used. First mean score and SD of all three groups were calculated.

Table 4. Results of one way ANOVA in pretest among all three groups

\begin{tabular}{|c|c|c|c|c|c|c|c|}
\hline & $\mathrm{N}$ & Mean & Std. Deviation & Levene Statistic & Sig. & $\mathrm{F}$ & Sig. \\
\hline Control & 31 & 9.35 & 4.046 & 2.303 & .106 & 2.003 & .141 \\
\hline TE & 31 & 9.65 & 2.870 & & & & \\
\hline TE + rule presentation & 31 & 11.00 & 3.347 & & & & \\
\hline
\end{tabular}

As can be seen in table 4, mean of control group is 9.35, TE group is 9.65 and TE+ rule presentation is 11 . Hence mean score of third group is higher than other two groups Levene Statistic test was run to see whether the difference in mean score in all 3 groups is significant or not. Based on the significant level of levene test 0/106> 
$0 / 05$, homogeneity of variances is confirmed. As can be seen in table four, level of significance is $0 / 141>0 / 05$; therefore, there is no significant difference among the groups in pretest. Therefore, it can be claimed that any measurable changes in the posttests is unlikely to be the effect of preexisting differences among the groups and, instead, can be attributed to the different treatments that the various groups experienced.

\subsection{Comparing Posttest in All Groups}

To compare post tests in all three groups two way mixed ANOVA was used. One of the hypotheses in two way ANOVA is the equality of variances. To test equality of variances Box test was used.

Table 5. Box's Test of Equality of Covariance Matrices ${ }^{\mathrm{a}}$

\begin{tabular}{ll}
\hline Box's M & 19.548 \\
\hline F & 1.550 \\
\hline df1 & 12 \\
\hline df2 & 39253.846 \\
\hline Sig. & .099 \\
\hline
\end{tabular}

Table 6. Results of mixed ANOVA on group effects and all three tests

\begin{tabular}{lllllll}
\hline Source & $\begin{array}{l}\text { Type III Sum of } \\
\text { Squares }\end{array}$ & df & Mean Square & F & Sig. & Partial Eta Squared \\
\hline factor1 & 2660.996 & 2 & 1330.498 & 164.109 & .000 & .646 \\
\hline Group & 579.620 & 2 & 289.810 & 4.858 & .010 & .097 \\
\hline factor1 * Group & 114.337 & 4 & 28.584 & 3.526 & .008 & .073 \\
\hline Error(factor1) & 1459.333 & 180 & 8.107 & & & \\
\hline Error(Group) & 5368.989 & 90 & 59.655 & & & \\
\hline
\end{tabular}

factor $1=$ pre, post 1 , post 2

group $=\mathrm{TE}, \mathrm{TE}+$ rule presentation, control group

Table 7. Results of LSD on comparing scores on all groups and tests (Pairwise Comparisons)

\begin{tabular}{lllll}
\hline (I) factor1 & (J) factor1 & $\begin{array}{l}\text { Mean Difference } \\
(\mathrm{I}-\mathrm{J})\end{array}$ & Std. Error & Sig. \\
\hline \multirow{2}{*}{ pre } & Post1 & $-6.882^{*}$ & .508 & .000 \\
\cline { 2 - 5 } & Post2 & $-6.161^{*}$ & .475 & .000 \\
\hline Post1 & Post2 & $.720^{*}$ & .199 & .000 \\
\hline (I) Group & (J) Group & $\begin{array}{l}\text { Mean Difference } \\
(\mathrm{I}-\mathrm{J})\end{array}$ & Std. Error & Sig. \\
\hline Control & TE & -1.90 & 1.133 & .096 \\
\hline TE & TE+ rule presentation & $-3.53^{*}$ & 1.133 & .002 \\
\cline { 2 - 5 } & TE+ rule presentation & -1.62 & 1.133 & .155 \\
\hline
\end{tabular}

As can be seen in table 5, level of significance found to be $0 / 099$. Because $0.099>0.05$ it can be concluded that matrices of variance and covariance is not in contrary of equality hypothesis. In addition, as it is shown in table 6 , level of significance found to be 0.000 . Because level of significance is smaller than 0.05 it can be concluded that effect of treatment is significant. It means that there is a significant difference among pretest, first posttest and delayed posttest. Results of LSD in table 7 show that before intervention pre test marks are significantly lower than first and second posttests. Posttest 1 is significantly higher than posttest 2. Furthermore effect of group is also significant. Level of significance is 0.01 . It means that there is a significant difference in these 3 groups. LSD results show that TE+ rule presentation group significantly outperformed the control group.

\subsection{Comparing Gender Differences in All Groups}

To compare gender difference in all three groups two way mixed ANOVA was used. One of the hypotheses in two way ANOVA is the equality of variances. To test equality of variances Box test was used. 
Table 8. Box's Test of Equality of Covariance Matrices

\begin{tabular}{llll}
\hline & Group Control & Group TE & Group TE + rule presentation \\
\hline Box's M & 6.692 & 6.533 & 8.183 \\
\hline F & .987 & .960 & 1.207 \\
\hline df1 & 6 & 6 & 6 \\
\hline df2 & 5456.191 & 4564.103 & 5456.191 \\
\hline Sig. & .432 & .450 & .299 \\
\hline
\end{tabular}

Table 9. Results of two way mixed ANOVA on gender effects on all tests and groups

\begin{tabular}{llllllll}
\hline Group & $\begin{array}{l}\text { Source TE+ } \\
\text { presentation }\end{array}$ & $\begin{array}{l}\text { Type III Sum } \\
\text { of Squares }\end{array}$ & df & Mean Square & F & Sig. & $\begin{array}{l}\text { Partial Eta } \\
\text { Squared }\end{array}$ \\
\hline \multirow{2}{*}{ Control } & factor1 & 446.486 & 2 & 223.243 & 32.123 & .000 & .526 \\
\cline { 2 - 8 } & Gender & 61.319 & 1 & 61.319 & .726 & .401 & .024 \\
\cline { 2 - 8 } & factor1 * Gender & 32.034 & 2 & 16.017 & 2.305 & .109 & .074 \\
\hline \multirow{2}{T}{ TE } & factor1 & 1068.299 & 2 & 534.150 & 63.062 & .000 & .685 \\
\cline { 2 - 8 } & Gender & .640 & 1 & .640 & .014 & .906 & .000 \\
\cline { 2 - 8 } & factor1 * Gender & 6.364 & 2 & 3.182 & .376 & .688 & .013 \\
\hline \multirow{2}{*}{$\begin{array}{l}\text { TE+ rule } \\
\text { presentatio } \\
\mathrm{n}\end{array}$} & factor1 & 1232.580 & 2 & 616.290 & 69.711 & .000 & .706 \\
\cline { 2 - 8 } & Gender & 120.627 & 1 & 120.627 & 2.428 & .130 & .077 \\
\cline { 2 - 8 } & factor1 * Gender & 13.827 & 2 & 6.914 & .782 & .462 & .026 \\
\hline
\end{tabular}

Table 10. Results of LSD for comparing all groups and tests (Pairwise Comparisons)

\begin{tabular}{|c|c|c|c|c|c|}
\hline Group & (I) factor 1 & $(\mathrm{~J})$ factor 1 & Mean Difference (I-J) & Std. Error & Sig. \\
\hline \multirow[t]{3}{*}{ Control } & \multirow[t]{2}{*}{ pre } & Post1 & $-4.868^{*}$ & .845 & .000 \\
\hline & & Post2 & $-4.443^{*}$ & .755 & .000 \\
\hline & Post1 & Post2 & .424 & .271 & .128 \\
\hline \multirow[t]{3}{*}{ TE } & \multirow[t]{2}{*}{ pre } & Post1 & $-7.350^{*}$ & .902 & .000 \\
\hline & & Post2 & $-7.218^{*}$ & .871 & .000 \\
\hline & Post1 & Post2 & .132 & .334 & .694 \\
\hline \multirow{3}{*}{$\begin{array}{l}\text { TE }+ \text { rule } \\
\text { presentation }\end{array}$} & pre & Post1 & $-8.403^{*}$ & .913 & .000 \\
\hline & & Post2 & $-6.893^{*}$ & .851 & .000 \\
\hline & Post1 & Post2 & $1.511^{*}$ & .412 & .001 \\
\hline
\end{tabular}

As table 8 shows, level of significance in control group found to be 0.432 . Because $0.432>0.05$ it can be concluded that matrices of variance and covariance is not in contrary of equality hypothesis. In addition, as can be seen in table 9, level of significance found to be 0.000 . Because level of significance is smaller than 0.05 it can be concluded that effect of treatment is significant. It means that there is a significant difference among pretest, first posttest and delayed posttest. Results of LSD in table 10 show that before intervention pre test marks are significantly lower than first and second posttests. Posttest1 is significantly higher than posttest2. However effect of gender in control group is not significant. Significant level found to be 0.401 , meaning that there isn't a significant difference between male and female students in their intake of simple past tense. Meanwhile the same method of analysis was used for TE group. Level of significance found to be 0.45 . Because $0.45>0.05$ it can be concluded that matrices of variance and covariance is not in contrary of equality hypothesis. In addition, Level of significance found to be 0.000 . Because Level of significance is smaller than 0.05 it can be concluded that effect of treatment is significant. It means that there is a significant difference among pretest, first posttest and delayed posttest. Results of LSD show that before intervention pre test marks are significantly lower than first and second posttests. Posttest 1 is significantly higher than posttest2. However effect of gender is not significant. Significant level found to be 0.906 , meaning that there isn't a significant difference between male and female students in their intake of simple past tense. Furthermore, based on the same method of analysis for $\mathrm{TE}+$ rule presentation group, level of significance found to be 0.299 . Because $0.299>0.05$ it can be concluded that matrices of variance and covariance is not in contrary of equality hypothesis. In addition, level of significance found to be 0.000 . Because Level of significance is smaller than 0.05 it can be concluded that effect 
of treatment is significant. It means that there is a significant difference among pretest, first posttest and delayed posttest. Results of LSD shows that before intervention pre test marks are significantly lower than first and second posttests. Posttest 1 is significantly higher than posttest2. However effect of gender is not significant. Significant level found to be 0.130 , meaning that there isn't a significant difference between male and female students in their intake of simple past tense.

\section{Discussion \& Conclusion}

As it was mentioned before, focus on form has attracted lots of attention in Second Language (SL) literature in the light of classroom research which supports the need for pedagogical interventions to push learners towards higher levels of proficiency in 12 ( Mitchell 2000; Norris \& Ortega 2000; Williams 2005, R. Ellis, 2006). Long (1991) defines FonF as overtly drawing learners' attention to linguistic elements as they arise incidentally in lessons whose overriding focus is on meaning or communication into tasks such as processing instruction, textual enhancement and linguistic or grammar problem-solving activities. Psycholinguistic rationales for the pedagogical recommendation of focus on form is provided by (Doughty, 2001). For Doughty, one of the essential assumptions of focusing on form is that focus on form should be brief and occur at the same time with focus on meaning, so that the interventions do not interfere with the macro processing of the comprehension and production. This kind of joint processing is claimed to "facilitate the cognitive mapping among forms, meaning, and use that is fundamental to language learning" (Doughty 2001, p. 211).

Furthermore, Williams (2005) claims that FonF tries to target how 12 learners a) notice words/forms in the input, b) notice the difference "the gap" between inter language and target language forms in the input, and c) incorporate target-like forms in their developing Inter language. Williams (2005) continues to claim that that the need for this approach is triggered when learners have problems or difficulties which usually results in a breakdown in communication. The problematic linguistic elements come into instructional focus to help learners get back on the track. As such, FonF is compatible with the communicative approaches (Muranoi, 2000; Basturkmen, Leowen, \& Ellis, 2006), especially when there is a need for learners to stretch their inter language resources for meeting the communicative task demands. Without it, learners who have limited 12 processing capacity experience difficulty in simultaneously attending to form and meaning.

The key aspect of FonF instruction is that meaning and use must be evident to the learner while attention is drown into the linguistic element needed to get the meaning across (Doughty and Williams 1998). R. Ellis (2003) claims that the need for this approach becomes even more significant when learners have acquired some communicative capability and when they are at the risk of fossilizing. It can occur through increasing the input pedagogical intervention frequency and enhancing the saliency of problematic linguistic features. However, these treatments are not supposed to develop immediate mastery of target structures. The main purpose of such treatments is highlightining the learners' awareness to facilitate further noticing and analysis of the target structures in subsequent input. The aim of such approach is a non-linear learning process to take place in the 12 classroom. Another purpose of it for individual learners is to progress according to a developmental sequence, which is not necessarily in step with explicit instruction. Therefore, there is a need to find a suitable instructional method to help learners attain linguistic accuracy in communicative language classrooms. As such, the present study investigated the effect of TE and TE + rule presentation intervention on intake of English simple past tense. The results of the study showed that TE is helpful in drawing learners' attention to the target form, subsequently leading to their intake of the form. Therefore, it can be inferred that textual enhancement helped the learners in attending to the target form. The result of the present study is in line with (Daugty 1991; Jourdenais et al. 1995; Lee 2007; Cho 2010) who reported positive effects of TE on both acquisition and noticing. However the result of the present study contrasts with some studies that reported no facilitative effects of TE (Izumi, 2002; 2001; Leow et al., 2003; Overstreet, 2002; Wong, 2003). Another finding of the study is that TE is more effective when it is combined with explicit rule presentation. Thus, the present study supports the claims that focus-on-form method of teaching draws learners' attention to form, in a generally meaning-oriented activity. Therefore the results of the present study confirms the claim made by some researchers (Harley \& Swain, 1984; Schmidt, 1983) that learners often don't notice forms in the input in spite of repeated exposure, claiming that explicit instruction can benefit learners in acquiring moderately difficult grammatical rules. For DeKeyser, (2003) benefit of explicit instruction can be its ability in triggering the incidental noticing of form-meaning connections within subsequent input.

Based on the results of the present study some pedagogical implications can be made. First, if effects of TE + rule presentation are found to be confirmed in future research, language instructors might feel more justified while using TE+ explicit instruction to target moderately difficult linguistic patterns when the instruction per se does not lead to immediate acquisition. Taking into consideration the grammar pedagogy, the present study may offer 
some evidence that TE can be an effective focus-on-form technique, at least for the English simple past tense and the EFL population investigated. The results can provide further insight into how learners utilize attentional resources when they are faced with textual input enhancement as a type of focus-on-form instructional intervention. At the same time, the study also shows that additional or alternative instruction $\mathrm{TE}+$ rule presentation is more beneficial in triggering learners' intake of the target form and thus the findings bolster a recommendation for some combination of explicit instruction plus textual enhancement.

\section{References}

Alanen, R. (1995). Input enhancement and rule presentation in second language acquisition. Attention and awareness in foreign language learning, 259-302.

Bitchener, J. (2008). Evidence in support of written corrective feedback. Journal of Second Language Writing, 17, 102-118. http://dx.doi.org/10.1016/j.jslw.2007.11.004

Basturkmen, H., Loewen, S., \& Ellis, R. (2004). Teachers' stated beliefs about incidental focus on form and their classroom practices. Applied Linguistics, 25(2), 243.

Canale, M., \& Swain, M. (1980). Theoretical bases of com-municative approaches to second language teaching and testing. Applied Linguistics, 1(1).

Cho, M. Y. (2010). The effects of input enhancement and written recall on noticing and acquisition. Innovation in Language Learning and Teaching, 4(1), 71-87. http://dx.doi.org/10.1080/17501220903388900

Combs, Ch. (2008). Topic familiarity and Input Enhancement: An empirical investigation. TESOL \& Applied Linguistics, 8(2).

Doughty, C. (1991). Second language instruction does make a difference. Studies in Second Language Acquisition, 13(04), 431-469. http://dx.doi.org/10.1017/S0272263100010287

Doughty, C. (2001). Cognitive underpinnings of focus on form. Cognition and second language instruction, 206-257.

Doughty, C. J. (2003). Instructed SLA: Constraints, compensation, and enhancement.

Doughty, C., \& Varela, E. (1998). Communicative focus on form. Focus on form in classroom second language acquisition, 114-138.

Doughty, C., \& Williams, J. (1998). Focus on form in classroom second language acquisition. Cambridge Univ Pr.

Ellis, R. (2003). Task-based language learning and teaching. Oxford University Press, USA.

Ellis, R. (2006). Current issues in the teaching of grammar: An SLA perspective. TESOL Quarterly, 40(1), 83-107.

Ferris, D. R. (2004). The "Grammar Correction" Debate in L2 Writing: Where are we, and where do we go from here? (and what do we do in the meantime...?). Journal of Second Language Writing, 13, 49-62. http://dx.doi.org/10.1016/j.jslw.2004.04.005

Gascoigne, C. (2006). Explicit input enhancement: Effects on target and non target aspects of second language acquisition. Foreign Language Annals, 39(4), 551-564.

Gass, S. M., \& Mackey, A. (2002). Frequency effects and second language acquisition. Studies in Second Language Acquisition, 24(02), 249-260.

Goldschneider, J. M., \& DeKeyser, R. M. (2005). Explaining the "Natural Order of L2 Morpheme Acquisition" in English: A Meta analysis of Multiple Determinants. Language learning, 55(S1), 27-77.

Harley, B. (1993). Instructional strategies and SLA in early French immersion. Studies in Second Language Acquisition, 15, 245-260.

Harmer, J. (2007). The practice of English language teaching (Fourth edition). Harlow: Longman.

Izumi, S. (2002). Output, input enhancement, and the noticing hypothesis. Studies in Second Language Acquisition, 24(04), 541-577.

Kelly, G. P. B. R. R. (2008). The Efficacy of Visual Input Enhancement in Teaching Deaf Learners of L2 English. Understanding second language process, 80.

Lee, S. K. (2007). Effects of textual enhancement and topic familiarity on Korean EFL students' reading comprehension and learning of passive form. Language learning, 57(1), 87-118. 
http://dx.doi.org/10.1111/j.1467-9922.2007.00400.x

Lee, S. K., \& Huang, H. T. (2008). Visual input enhancement and grammar learning: A meta-analytic review. Studies in Second Language Acquisition, 30(03), 307-331.

Leow, R. (1997). The effects of input enhancement and text length on adult L2 readers' comprehension and intake in second language acquisition. Applied Language Learning, 8, 151-182.

Leow, R. P. (1998). Toward operationalizing the process of attention in SLA: Evidence for Tomlin and Villa's (1994) finegrained analysis of attention. Applied Psycholinguistics, 19(01), 133-159.

Leow, R. P. (2001). Do learners notice enhanced forms while interacting with the L2?: An online and offline study of the role of written input enhancement in L2 reading. Hispania, 84(3), 496-509. http://dx.doi.org/10.2307/3657810

Leow, R. P., \& Morgan-Short, K. (2004). To think aloud or not to think aloud: The issue of reactivity in SLA research methodology. Studies in Second Language Acquisition, 26(01), 35-57.

Leow, R. E. T., Nuevo, A. M., \& Tsai, Y. C. (2003). The roles of textual enhancement and type of linguistic item in adult L2 learners' comprehension and intake. Applied Language Learning, 13, 1-16.

Long, M. H. (1991). Focus on form: A design feature in language teaching methodology. In K. De Bot, R. B. Ginsberg, \& C. Kramsch (Eds.), Foreign language research in cross- cultural perspective (pp. 39-52). Philadelphia: Benjamins.

Long, M. H. (1998). Focus on form Theory, research, and practice Michael H. Long Peter Robinson. Focus on form in classroom second language acquisition, 15.

Mitchell, R. (2000). Anniversary article. Applied linguistics and evidence-based classroom practice: the case of foreign language grammar pedagogy. Applied Linguistics, 21(3), 281.

Mueller, C. M. (2010). Effects of Explicit Instruction on Incidental Noticing of Metaphorical Word Sequences during a Subsequent Reading Task. International Journal of English Studies, 10(1), 81-101.

Muranoi, H. (2000). Focus on form through interaction enhancement: Integrating formal instruction into a communicative task in EFL classrooms. Language Learning, 50, 617-673.

Norris, J. M., \& Ortega, L. (2000). Effectiveness of L2 instruction: A research synthesis and quantitative meta analysis. Language learning, 50(3), 417-528.

Overstreet, M. (1998). Text enhancement and content familiarity: The focus of learner attention. Spanish Applied Linguistics, 2, 229-258.

Overstreet, M. (2002). The effects of textual enhancement on second language learner reading comprehension and form recognition. Unpublished doctoral dissertation, University of Illinois at Urbana-Champaign.

Rezvani, A. (2011). The Effect of Output Requirement on the Acquisition of Grammatical Collocations by Iranian EFL Learners. Journal of Language Teaching and Research, 2(3), 674-682. http://dx.doi.org/10.4304/jltr.2.3.674-682

Robinson, P. (1995). Attention, memory, and the "noticing" hypothesis. Language learning, 45(2), 283-331.

Robinson, P. (1997). Individual differences and the fundamental similarity of implicit and explicit adult second language learning. Language learning, 47(1), 45-99.

Sarkhosh, M., \& Sarboland, E. (2012). Different Textual Enhancement Formats and the Intake of English Past Simple Tense. International Journal of Linguistics, 4(2), 459-474. http://dx.doi.org/10.5296/ijl.v4i2.1861

Schmidt, R. (1993). Consciousness, learning and interlanguage pragmatics. Interlanguage pragmatics, 21, 42.

Schmidt, R. (1995). Consciousness and foreign language learning: A tutorial on the role of attention and awareness in learning. Attention and awareness in foreign language learning, 1-63.

Schmidt, R. (2001). Attention. In P. Robinson (Ed.), Cognition and second language instruction (pp. 3-32). New York: Cambridge University Press.

Sheen, R. (2002). Focus on form' and 'focus on forms. ELT Journal, 56, 303-304.

Simard, D. (2009). Differential effects of textual enhancement formats on intake. System, 37(1), 124-135. http://dx.doi.org/10.1016/j.system.2008.06.005

Simard, D., \& Wong, W. (2004). Language awareness and its multiple possibilities for the L2 classroom. Foreign 
Language Annals, 37(1), 96-110.

Smith, M. S. (1993). Input enhancement in instructed SLA. Studies in Second Language Acquisition, 15(02), 165-179. http://dx.doi.org/10.1017/S0272263100011943

Song, M. (2007). Getting learners' attention: Typographical input enhancement, output, and their combined effects. English Teaching, 62, 193-215.

Trahey, M., \& White, L. (1993). Positive evidence and preemption in the second language classroom. Studies in Second Language Acquisition, 15(02), 181-204.

VanPatten, B. (1994). Explicit instruction and input processing. Studies in Second Language Acquisition, 15 , $25-41$.

VanPatten, B. (2004). Input processing in second language acquisition. Processing instruction: Theory, research, and commentary, 5-31.

Williams, J. (2005). Form-focused instruction. In E. Hinkel (Ed.), Handbook of research in second language teaching and learning (pp. 671-692). Mahwah, NJ: Lawrence Erlbaum.

White, J. (1998). Getting the learners' attention: A typographical input enhancement study. Focus on form in classroom second language acquisition, 85-113.

Wong, W. (2003). Textual Enhancement and Simplified Input: Effects on L2 Comprehension and Acquistition of Non-meaningful Grammatical Form. Applied Language Learning, 13, 109-132.

Wong, W. (2005). Input enhancement: From theory and research to the classroom. McGraw-Hill. 